\title{
Decision-makers impact on the internationalization of high-technology firms in emerging markets
}

\author{
Michael Neubert ${ }^{1 *}$ (D) and Augustinus Stijn Van Der Krogt ${ }^{2}$ (D)
}

\author{
* Correspondence: michael. \\ neubert@faculty.ism.edu \\ ${ }^{1}$ ISM International School of \\ Management, 17, Boulevard Raspail, \\ 75007 Paris, France \\ Full list of author information is \\ available at the end of the article
}

\begin{abstract}
This study examines the impact of decision-makers from Paraguayan software firms on internationalization. It aims to have a better understanding about the (non-) rational decision logic of the CEOs and founders shaping the internationalization processes of 45 Paraguayan software firms. This study uses an observational, comparative descriptive, and a descriptive, correlational-research design based on a survey with the CEOs and founders of 45 Paraguayan software firms. The results suggest a significant correlational impact of decision-makers' characteristics on the software firm's internationalization and calls for further collaboration with high-tech firms from different industries in emerging as well as developed markets.
\end{abstract}

Keywords: International entrepreneurship, High-tech firms, Uppsala model, Paraguay, Decision-making, Internationalization, Emerging markets

\section{Introduction}

Similarly to technology industries in other countries, there is a need in the Paraguayan software enterprises to understand the extent to which decision-makers affect their exports. Today, the open market model (OMM) in Paraguay has contributed to a growing number of small innovative software firms. With increasing globalization in the information and technology sector, there is a need for the local firms to expand their innovative products into the international markets. Doing this would ensure their growth and demand expansion due to their small size in the home market (Neubert \& Van Der Krogt, 2017, 2018). Therefore, future competitiveness and sustainability in the Paraguayan software sector may be better achieved by equipping decision-makers adequately to develop and venture into foreign markets.

The above considerations underlay the purpose of this study, which was the impact of decision-makers on Paraguayan software exports and internationalization. The Uppsala internationalization process model (UIPM) was used as a theoretical framework. Moreover, it is what underlay all the above considerations. The motivation to undertake this research was inspired by recommendations made by Gulanowski, Papadopoulos, and Plante (2018), Coviello, Kano, and Liesch (2017), and Vahlne and Johanson (2017). These further investigate the gap in the literature on the impact of

(c) The Author(s). 2019 Open Access This article is distributed under the terms of the Creative Commons Attribution 4.0 International License (http://creativecommons.org/licenses/by/4.0/), which permits unrestricted use, distribution, and reproduction in any medium, provided you give appropriate credit to the original author(s) and the source, provide a link to the Creative Commons license, and indicate if changes were made. 
decision-makers on Paraguayan software exports and internationalization activities. Furthermore, this study sought to expand and continue the research by Neubert and Van Der Krogt $(2017,2018)$ on the internationalization of high-tech firms and export performance of software companies in emerging economies such as Paraguay. Consequently, the existing gap in the literature emphasizes the need for further research regarding the impact of decision-makers on the internationalization of high-tech firms in emerging markets, while using the UIPM as the theoretical framework.

Research on the factors that influence the globalization of small and medium-sized enterprises (SMEs) continues to attract growing interest in both practitioner and scholarly literature (Cerrato \& Piva, 2015; Musso \& Francioni, 2012). Since this is an emerging topic, especially in Paraguay, there are a limited number of empirical studies that have investigated the impact of decision-makers on the internationalization of hightechnology firms in emerging markets. As such, the extant literature agrees with the fact that further research is needed on this topic to explore better and comprehend how decision-makers influence the internationalization of SMEs (Coviello et al., 2017; Gulanowski et al., 2018).

Such a research approach is essential because according to Cerrato and Piva (2015) SMEs that aspire to venture into international markets largely rely on the network and experience of decision-makers to select and grow new markets. Also, SMEs with internationalization prospects depend on the insights from their decision-makers to acquire new business ventures in their target markets as an avenue to successful market entry (Gulanowski et al., 2018). According to Neubert (2018a) and Neubert and Van Der Krogt (2018), decision-makers have increasingly focused on using business intelligence to enhance their decision processes in creating new networks plus as a means of gaining reliable knowledge about new international markets.

The current research approach is based on quantitative analysis and on data collected from face-to-face surveys. The choice of this approach was informed by a descriptive, correlational-research design proposed by Coviello et al. (2017). According to Coviello et al. (2017), there is a paucity of quantitative methods when examining the impact that decision-makers have on the internationalization of high-technology firms in emerging markets. Considering the significance of dynamic and rapid changes in the internationalization process, Neubert and Van Der Krogt (2017) have recently pointed out that the projected impact of decision-makers in this process may be central in the success of globalizing Paraguayan software firms, an aspect that is of primary research interest in this study.

Having presented the research background, which informs this study, the subsequent sections are organized as follows: first, the study presents and discusses past and current literature studies on the topic with a specific focus on the Uppsala internationalization process model, which is the theoretical framework selected for this research (Vahlne \& Johanson, 2017). Second, the study presents the research methodology including the sampling strategy and the research questions. Third, the research questions are answered based on the findings of this study. Subsequently, these results are discussed and compared with research results from other studies. Finally, the article concludes with a list of key findings, an analysis of the impact of the research results, and recommendations for further research. 


\section{Literature review and theoretical framework}

In the last four decades, the UIPM has been a widely cited and criticized theoretical framework in the literature (Coudounaris, 2018; Gulanowski et al., 2018; Håkanson \& Kappen, 2017). Primarily, the UIPM framework has played a fundamental role in describing the initial stages that firms undergo in their internationalization prospects (Neubert, 2015; Santangelo \& Meyer, 2017). For instance, past studies by Johanson and Vahlne (2009) and Vahlne \& Johanson $(2013,2017)$ have explored how the UIPM framework can be applied to a changing international business environment and subsequent advancement in the internationalization process. In the same context, Coviello et al. (2017) advocated the need for further research to be undertaken to understand how macro-level aspects, such as decision-makers and digitalization impact the UIPM framework. Figure 1 presents a detailed elaboration of the UIPM theoretical framework, which was used in this study.

Neubert and Van Der Krogt (2017) initially examined the behavior of Paraguayan software firms and later assessed the impact that business intelligence has on the export performance of these business startups (Neubert \& Van Der Krogt, 2018). More recently, Neubert (2018b) compared the behavior of Paraguayan software firms and the impact of business intelligence on export performance from other emerging markets (Neubert, 2018b) as well as software firms from developed markets (Neubert, 2018a). The results from these revealed that although there are a small number of decisionmakers of Paraguayan software firms, they are increasingly embracing and using business intelligence solutions to facilitate their international decision-making process. According to Neubert and Van Der Krogt (2018), this growing trend can be explained by the surging optimism about the impact of business intelligence on enhanced export performance and international competitiveness.

This study is framed by the structure of the Paraguayan software industry. Based on estimations of the "Encuesta de empresas del sector de TICs" Senatics (2014), 50 companies are active in software development and related advisory services. The 45 companies, which participated in this research, represent $90 \%$ of the total sub-sector. Eighty-nine percent are domiciled in the Paraguayan capital Asuncion and the other $11 \%$ in the second largest city Ciudad del Este. Eighty-four percent are involved in software development and 16\% in related advisory services. 1.172 employees produce an

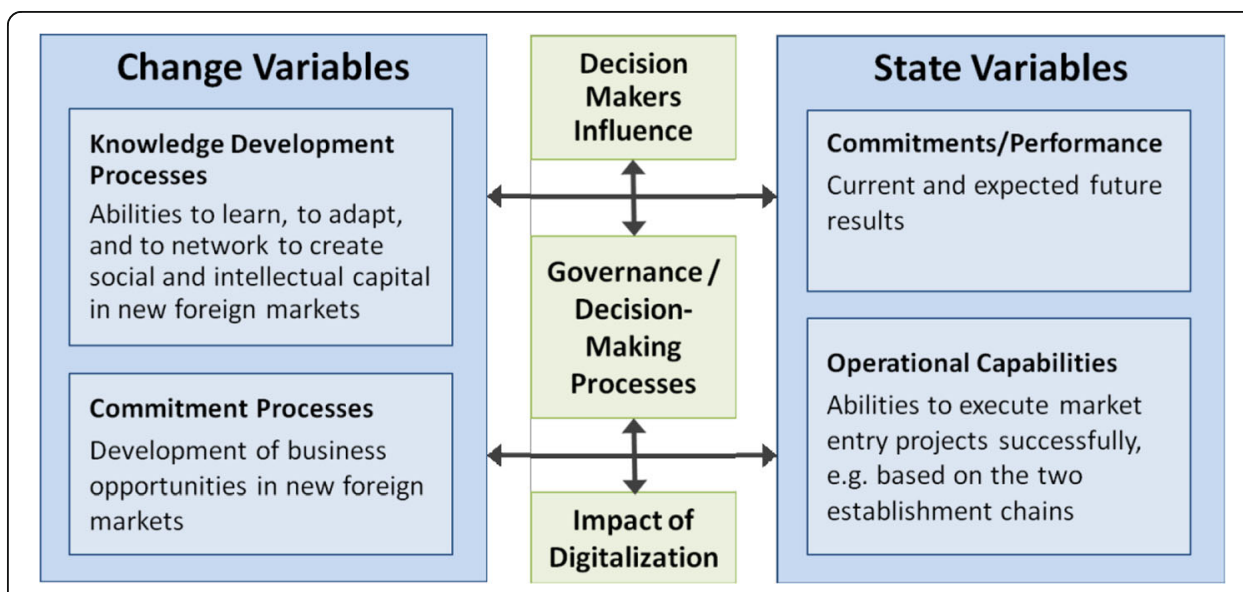

Fig. 1 Theoretical framework based on the UIPM (Coviello et al., 2017; Vahlne \& Johanson, 2017) 
average turnover of 112,000 USD per employee and 2,982,000 USD per company; $60 \%$ of this subsector exports, which is more than twice the average of the entire ICT sector (25\%). All companies are family-owned and external investment is still uncommon. If there are any external shareholders, for example, business angels and employees, they are minority shareholders without significant influence on the decision-making processes.

In their theoretical model, Vahlne and Johanson (2017) and Coviello et al. (2017) underlined the importance of decision-makers influence on business internationalization (Fig. 1). Vahlne and Johanson (2017) introduced the variable "decision-makers' job experience" explaining how the knowledge gained through experience affects international decision-making processes and business internationalization. The variable "decision-makers' job experience" is an integral part of the UIPM (Vahlne \& Johanson, 2017) describing how to exploit international business opportunities through networking and market experience. In our sample, $40 \%$ of the 45 SMEs have more than 20 years of job experience, $42 \%$ between 10 and 19 years, and 18\% between 5 and 10 years. Coviello et al. (2017) initiated the discussion about digitalization in internationalization research. The variable "decision-makers' business intelligence knowledge" describes the ability of decisions-makers to use businessintelligence software in international decision-making processes and business internationalization (Neubert \& Van Der Krogt, 2018). In our sample, 60\% of the 45 SMEs estimated their business intelligence knowledge as advanced, $33 \%$ as basic, and $7 \%$ as low.

Existing trends reveal that Paraguayan software firms prefer selecting and entering new international markets based on three main considerations. These are to follow existing clients with little analysis on the attractiveness of foreign markets, the availability of new market opportunities, and that the selections are based on their existing networks (Neubert \& Van Der Krogt, 2017). These observations by Neubert and Van Der Krogt (2017) have been partially confirmed by Ooi and Richardson (2019) who have recently argued that business capabilities, business networks, and psychic distances influence the internationalization of high-tech businesses from emerging markets such as Malaysia. As such, a similar assumption can also be applied to the software startup firms from emerging markets like Paraguay.

Based on the recent update on the UIPM model in 2017, there are two main state variables and change variables of interest as shown in Fig. 1 (Vahlne \& Johanson, 2017). First, the state variables are attributed to "commitments/performances" and "capabilities" (Vahlne \& Johanson, 2017). Second, the change variables of the UIPM model refer to "commitment processes" and "knowledge development processes" (Vahlne \& Johanson, 2017). The arrows are used to indicate the relationship, which exists between state and change variables. For instance, dedicating more resources to a foreign market or acquiring additional business knowledge significantly influences a software company's capabilities and performance in the market.

In this study, the UIPM framework based on the entrepreneurial knowledge development process is used considering that the Paraguayan software companies who were invited into this study are entrepreneurial in nature. As such, the founders or owners in this study manage the selected companies or software firms. According to Vahlne and Johanson (2017), the process is composed of three elements. 
1. Relationship building—such as building trust with new distributors and clients, as well as creating new business opportunities.

2. Strategic flexibility.

3. Adaptability to the working environment (Vahlne \& Johanson, 2017).

The ability to have networks (i.e., creating social capital), adapting, and learning (i.e., creating intellectual capital) promotes the development of firm-specific and marketspecific advantages. When applied and implemented effectively, learned abilities and intellectual and network processes enhance successful market entry for software companies. Additionally, another important change variable in the UIPM framework is "commitment processes." As applied to this study, commitment processes refer to "opportunity development" in the foreign markets (Vahlne \& Johanson, 2017). In elaboration, opportunity development describes the ability of software firms to identify, acquire, and develop new business opportunities in foreign markets.

While exploring the aspect of "operational capabilities," Vahlne and Johanson (2017) elaborated one of the most fundamental elements of the UIPM framework-which is based on "establishment chains." The concept of establishment chains is further detailed in Fig. 2. Often, high-tech enterprises such as the software firms in Paraguay embrace establishment chains as a channel through which they enter new foreign markets. The first step under this internationalization process for the Paraguayan software enterprises is to enter culturally and geographically proximate markets. In this case, the close markets include Argentina, Bolivia, and Brazil all which are perceived to be of low-risk and also require or consume low resources to enter the markets in terms of "software licensing" or "service export." Moreover, collaboration with domestic distributors is easier and cost-effective during the initial entry phase (Neubert, 2017; Neubert \& Van Der Krogt, 2017). According to Neubert and Van Der Krogt (2018), the process is referred to as the market distance establishment chain (Fig. 2).

As the Paraguayan software firms grow increasingly successful in the new foreign markets, they may end up increasing their presence in these markets. According to Neubert and Van Der Krogt (2017), the firms may focus on establishing a wholly owned subsidiary or acquire their local distributor. As shown in Fig. 2, this process is called "the market commitment establishment chain." Furthermore, these firms also start joining more distant foreign markets like Mexico and Chile. Alternatively, the

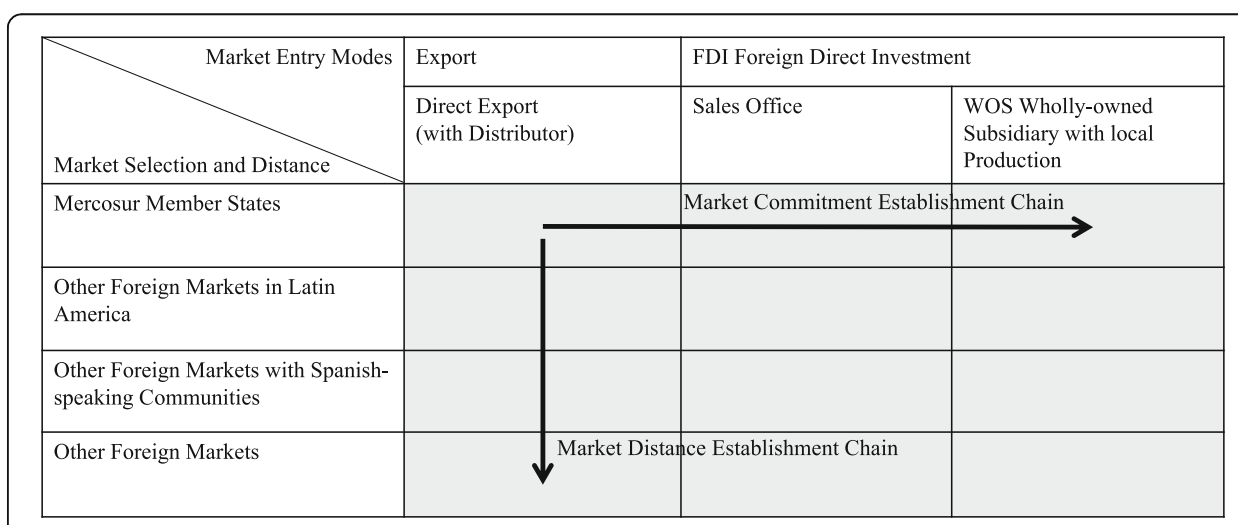

Fig. 2 Market distance and market commitment establishment chain (Neubert \& Van Der Krogt, 2018) 
software firms may opt to follow the existing markets that are at reach, but even distant markets. However, the attractiveness of foreign markets is often a dynamic and volatile process. Clarke and Liesch (2017) pointed out that due to the volatility of new markets, the software firms might experience the quick acquisition of new clients or loss of the established sales segments and in the process result in reduced market share commitment. In some cases, market volatility might force the new software companies in foreign markets to close down and exit (Sapouna, Dimitratos, Larimo, \& Zucchella, 2018).

Vahlne and Johanson (2017) also elaborated on other elements important to the UIPM, which include issues like outsidership and foreigner liabilities. For example, for the Paraguayan software firms to compensate for possible liabilities and outsidership, they need to have in place strong and sufficient market-specific and firmspecific advantages (Vahlne \& Johanson, 2017). Some of the firm-specific and marketspecific advantages that Paraguayan software firms have included are lower costs when compared to software enterprises from North American competitors. In addition, the Paraguayan software firms lie within the same time zone as their target clients from the USA compared to their other low-cost software competitors from countries like India. Specifically, firms from Paraguay are better positioned to communicate with clients from the USA during regular working hours, and in the same language, and these cultural aspects are highly valued by US clients. As a result of this specific competitive advantage, it can be noted that Paraguayan software firms mostly enter the US market earlier than anticipated when using the "market distance establishment chain" of the UIPM (Neubert \& Van Der Krogt, 2017).

Magnani, Zucchella, and Floriani (2018) shared that liability for foreignness and outsidership is large when the cultural, administrative, geographic, linguistic, and economic distances between the home market and foreign market are large. In the process, Vahlne and Johanson (2017) pointed out that when these disparities are considerable, there is a higher need for firm-specific competitive advantages. For example, software firms and their employees share similar attributes such as culture and tools (e.g., software), similar technical language, and methodologies (e.g., agile programming) (Vahlne \& Johanson, 2017). Thus, this familiarity with the same language, methodologies, and technologies reduces the liabilities that originate from outsidership and foreignness. When considering the Paraguayan software SMEs, it may be more prudent to enter the growing and developed markets in North America, Europe, or East Asia as opposed to targeting neighboring emerging markets due to their specific market opportunities or their market attractiveness. The active market entry strategies are further presented in Fig. 3.

The distances to the foreign markets for the Paraguayan software enterprises are bridged with the help of domestic distributors. Besides, local distributors play an important role in helping Paraguayan firms to adapt their terms of doing business (e.g., warranties and payment conditions), marketing communication, pricing, and product features (Vahlne \& Johanson, 2017). Moreover, local distributors might offer services such as accounts receivable management, client service and acquisition, logistics, compliance, legal advice, and importing-related services (Neubert, 2018b). Yamin and Kurt (2018) further indicated that distributors provide access to domestic clients and market knowledge to foreign firms, and this process serves to increase the speed of market entry when compared to the hierarchical model of market entry. In elaboration, it can be argued that the speed of internationalization is largely influenced by the level of 


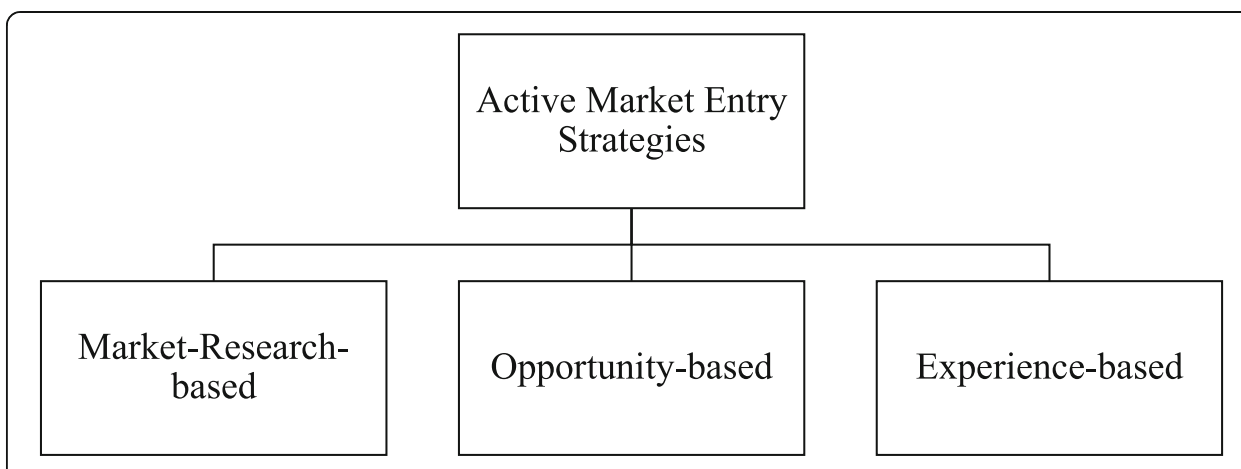

Fig. 3 Active market entry strategies (Neubert, 2018a, 2018b)

network and knowledge creation in a new foreign market, preferably with the support of domestic partners (Neubert, 2017; Vahlne \& Johanson, 2017). In addition to the important role that domestic distributors play, digitalization may also contribute to disintermediation when Paraguayan firms opt to use online distribution and marketing channels such as social media.

However, since Paraguayan firms use digital technologies during selection and evaluation phases, these SMEs end up having limited possibilities in terms of their choice of foreign markets (Coviello et al., 2017; Neubert, 2018b), especially when going through the internationalization process, as elaborated in Fig. 4. Instead of basing their decisions on their own criteria of individual experiences, the Paraguayan firms base their choices on the availability or the appeal of opportunities in the foreign markets. In most situations, these software firms use all possible approaches in identifying the most attractive foreign markets from the firms' perspectives, in addition to the perspective of the decision-makers (Johanson \& Vahlne, 2009). Therefore, the cultural background, international experience, and personal networks of the management board, non-executive directors, and founders largely influence the selection of foreign markets and the manner in which a business will enter these foreign markets (Coviello et al., 2017). The main goal of this study, therefore, was to gain a better understanding of the (non)-rational decision logic of the persons who shape the software firm's internationalization process.

With the emergence of new business models like international new ventures (INV) (Knight \& Liesch, 2016), born global firms (BGF) (Knight \& Liesch, 2016), and like lean global startup (LGS) (Neubert, 2018a, 2018b), the literature started to calculate the possibility of applying the UIPM on these new types of technology firms (Coviello et al., 2017; Vahlne \& Johanson, 2017). For instance, BGFs are considered to be high-tech start-up firms (HSF) - often domiciled in small and open economies (SMOPEC)-with patent protected "new-to-the-world" products (Kriz \& Welch, 2018). Their patent protection applies to the global market, and often, these firms prefer to enter the foreign

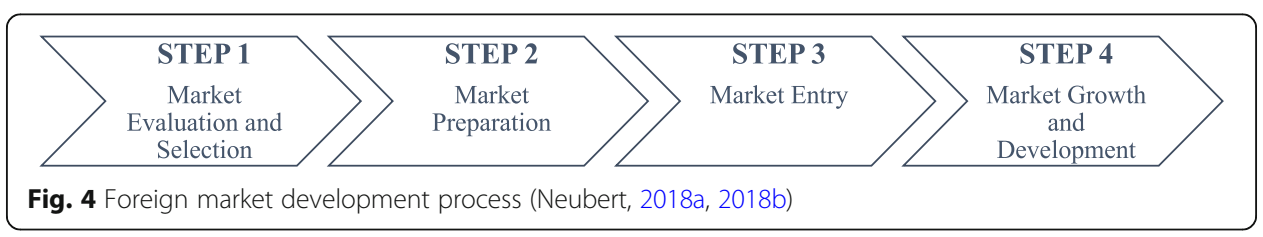


market fast and early (Johanson \& Vahlne, 2009) in efforts to leverage their technology using foreign-market penetration strategy as opposed to increasing their presence in individual foreign markets. The firms in this study's sample are software firms without a patent-protected product. They look for international business opportunities as soon as they have developed a competitive product or service. Therefore, their business model might be described as a BGF from an emerging IT market in its early stages (Neubert \& Van Der Krogt, 2017).

Even though the HSFs prefer to continue collaborating with their local distributors and to export their products, the HSFs largely remain committed to their markets (Gulanowski et al., 2018; Vahlne \& Johanson, 2017). Similar to other software firms, HSFs also base their incremental internationalization paths on FSA, although they may deviate from the market distance establishment chain (Gulanowski et al., 2018). According to Falahat, Knight, and Alon (2018), the international market performance of the HSFs is commonly influenced by the quality of their international market strategy, which is anchored on their own networking ability and international learning. Having discussed the past literature studies which reflect the current research topic, the next section presents and discusses the research methods and approaches used to collect and analyze the relevant data and answer the formulated research questions.

\section{Methods}

Research philosophy, approach, and strategy

The choice for research methodology was informed by the aim and objectives of this study. Specifically, this purpose of this study aimed at creating a better understanding of the (non)rational decision logic of those individuals shaping the firm's internationalization process. The philosophical framework was based on epistemological positivism and ontological objectivism. Easterby-Smith, Thorpe, and Jackson (2014) pointed out that positivism and objectivism entail a system of beliefs where research interpretations are made by an individual and concerns what constitutes facts and reality about the world. In this study, positivism and objectivism are closely tied to quantitative research, which was used in this study to collect data from the participants.

The research approach was based on deductive logic or reasoning, which is the process of assessing the research phenomenon from one or more premises to reach a logically certain conclusion (Bryman, 2012; Gulati, 2009). In addition, the research strategy involved the use of case-study majoring on Paraguayan software firms. The focus on the case-study approach was informed by the need to undertake detailed analysis and in-depth assessment (Yin, 2017) of Paraguayan software companies regarding the impact of decision-makers on their internationalization process. To meet the aims and objectives of this study, two research methodologies were used.

\section{Research methodology}

The first research methodology entails the use of observational and comparative descriptive research design using a descriptive survey to report the characteristics of the sample at one point in time. It seeks to describe the current status of the collected variables or the characteristics of our population (Creswell \& Creswell, 2017). After the data is collected, the development of the hypotheses begins (Creswell \& 
Creswell, 2017). The purpose of this hypothesis testing is to determine whether there is a statistical significant relationship between decision-makers job experience and business-intelligence knowledge on the internationalization of Paraguayan SMEs (Creswell \& Creswell, 2017). The second methodology used in this study is a descriptive correlational-research design, which explores and observes the direction and strength of the relationship between two variables using statistical analyses to make broad generalizations. It is also based on a survey. However, it does not look for cause and effect and therefore is also mostly observational in terms of data collection (Creswell \& Creswell, 2017). A multiple-case study research design might have been another methodology to analyze the dataset, but would not have allowed the researchers to explore statistical significant relationships between variables.

\section{Hypothesis}

The specific hypotheses to be tested in this study postulate that:

Null hypothesis $\left(\mathbf{H}_{\mathbf{0}}\right)$ : There is no statistically significant relationship between decisionmakers job experience and business-intelligence knowledge on the internationalization of Paraguayan SMEs.

Alternative hypothesis $\left(\mathbf{H}_{\mathbf{a}}\right)$ : There is a statistically significant relationship between decision-makers job experience and business-intelligence knowledge on the internationalization of Paraguayan SMEs.

\section{Sampling strategy}

The choice of the sampling strategy is based on the purpose of the study. A study conducted by the National Secretary of Technology and Information (Secretaría Nacional de Tecnologías de la Información y Comunicación Encuesta de Empresas del sector de TICs', Observatorio TICs, Senatics, 2016) lists a total of 316 companies active in the ICT sector in Paraguay. Considering the fast growth in ICT companies since 2014, this group of companies represents an estimated $80 \%$ of the total number of companies active in the sector in 2018. There are no well-based data on the overall turnover of the ICT sector. Estimations based on the Senatics study indicate total sector revenues at around US\$ 460 million estimations based on "Encuesta de empresas del sector de TICs." (Senatics, 2014). The figure from 2014 represents about 1.5\% of the Gross Domestic Product of Paraguay (World Bank, 2016).

The subsector sampled out for this study comprises of 50 companies from this sector that are active in software development and related advisory services. The total population of 50 companies in this software development company in Paraguay was contacted and is out of this sample; 45 firms expressed interest in participating directly in the interviews. This represents data with a confidence level of $95 \%$ and a margin of error of five percent on the full population of Paraguayan software companies active in software development and related advisory services. The selected 45 companies were deemed to be a representative sample of the analyzed.

\section{Data collection}

The data collection process used a descriptive survey to collect responses of the sample using face-to-face interviews based on a structured questionnaire (instrument). The 
interviews took place in October and November 2018. Each interview lasted on average for $1 \mathrm{~h}$. Before the interviews took place, a pilot test was implemented to optimize the instrument/questionnaire, and then more questions were added to it.

\section{Data analysis}

Quantitative descriptive and correlational statistics are used to analyze the collected data to understand whether the variables are correlated and if yes what is the strength of their correlation (Bryman, 2012). Therefore, SPSS for Mac Version 25 was used to describe the characteristics of the sample at one point in time and to identify relationships between the different variables collected in the survey. The Pearson's correlation, which is considered as the best measure of correlation (Bryman, 2012), was set to 95\% $\mathrm{CI}$ where values $\leq 0.05$ were considered significant.

\section{Validity and reliability}

External validity refers to the extent to which results of a particular study are generalizable, or applicable, to other groups or settings. To guarantee external validity and to allow the generalizability of the findings, the researchers of this study contacted the total population (50). The management of 45 companies responded and was interviewed. Thus, the response rate is $95 \%$ (45 out of 50). Further, the instrument/questionnaire was pretested to guarantee reliability and Cronbach's alpha was calculated to understand the internal consistency. The validity of the results is also tested used statistical regression models like ANOVA or $T$ tests.

\section{Results}

\section{Reliability coefficient}

To increase the reliability of the survey data collected and to minimize potential errors in the instrument used to collect data, Cronbach's coefficient alpha was used. A value of 0.871 was obtained indicating that the instrument was accepted to be highly reliable. Goddard and Melville (2004) pointed out that in most social-science research situations, a reliability coefficient of more than 0.70 or higher should be considered "acceptable." Thus, in this study, a value of 0.871 suggests that the survey items used in collecting data have a relatively high internal consistency (Goddard \& Melville, 2004).

\section{Cross tabulations of industry and demographic characteristics}

Out of the 50 Paraguayan software firms invited to take part in this study, 45 completed the interview sessions representing a response rate of $90 \%$. Out of these respondents, $80 \%$ were Paraguayan while $20 \%$ were foreign. By the age group, most participants $(71 \%)$ fell within the 30-49 age bracket, followed by persons $>50$ years of age (24\%), while $4 \%$ were within the $20-29$ age bracket. The majority of the respondents $(53 \%)$ had postgraduate degrees, followed by $38 \%$ who were university graduates, and $9 \%$ with professional education qualifications. In terms of company ownership, $73 \%$ were company owners, $13 \%$ were directors, and $13 \%$ held management positions. When assessing the experience of the participants, $42 \%$ had $10-19$ years of work experience, with $40 \%$ having $>20$ years of experience, and $18 \%$ between 5 and 10 years of work experience. Regarding knowledge about business intelligence, the majority (60\%) 
had advanced knowledge in this area while 33\% had basic knowledge, and 7\% lacked any knowledge on the topic. In contrast, 53\% had advanced knowledge for decisionmaking in business intelligence systems, followed by $36 \%$ and $11 \%$ who had basic to no knowledge at all about business intelligence, respectively. In terms of business activity, $84 \%$ of the firms majored in software development and 16\% in software related developments. The demographic information on age, company position, years of experience, and knowledge about business intelligence shows that the participants possessed a surprisingly high level of knowledge in software development enterprises and were in an excellent position to respond to the questions asked in this study.

\section{Decision-maker's impact on a firm's internationalization}

There is a large spread in turnover software among the Paraguayan companies. The Paraguayan software companies have an average turnover of USD 112,000, which is much lower than average turnover per overall employee level of USD 200,000. The participants were asked about the average turnover in their companies and the results revealed that there is no correlation $(p>0.05)$ between turnover $(p=.165)$ and use of business intelligence $(p=.278)$. Assessment on the number of foreign markets revealed that only $25 \%$ of the firms are involved in exports. Further statistical analysis was performed to examine how key decision-makers in the Paraguayan software firms influence the internationalization of these firms. The assessment explores 27 decisionmaking criteria grouped into six phases of the decision-making processes.

Phase 1 was designed to explore whether decision-makers establish a positive decision-making environment before internationalizing their operations. The feedback revealed that $51 \%$ of the company leaders tend to analyze the basic causes and problems or applied a structured process $(47 \%)$ before making decisions. Further, a twotailed correlation coefficient test revealed that there is a positive correlation $(p<0.01 ; p$ $=.513$ ) between a well-structured decision process and the use of business intelligence systems. Importantly, the majority of company leaders tend to involve other stakeholders in the preparations of decisions. Table 1 presents the bivariate correlation for four factors tested in phase 1 .

In phase 2, the decision-making process examined six criteria as summarized in Table 2. The results revealed that criterion 9 and 10 were correlated with the internationalization process. That is they searched for solutions with the lowest risk and cost (resource requirements) and used business intelligence software solutions to make decisions about the internationalization of Paraguayan software firms.

Moreover, criterion $6(p>0.01)$ and criterion $7(p>0.05)$ both had a positive association with criterion 10 where learning from the successful internationalization strategies of the competitors and considering diverse potential solutions like comparing different market entry modes before making decisions helped make informed decision outcomes.

Phase 3 showed that out of the four criteria used, only criterion 13 had a negative correlation with the decision-making process, that is, choice selection and implementation difficulties negatively affect Paraguayan software firms' internationalization process. In contrast, the other factors such as evaluating risks with alternatives, assessing risks versus consequences, and using business intelligence software to compare costs, 
Table 1 Correlation results for phase 1 analysis

\begin{tabular}{lllll}
\hline & Criterion & Criterion & Criterion & Criterion \\
& 1 & 2 & 3 & 4 \\
\hline $\begin{array}{l}\text { Criterion 1: Determine the real issue before starting a decision- } \\
\text { making process. }\end{array}$ & 1 & & & \\
Criterion 2: Use of well-defined structure in decision processes. & $.584^{* *}$ & 1 & & \\
Criterion 3: Support friends and find proposals to make them work. & -.086 & .146 & 1 & \\
Criterion 4: Prefer making decisions individually. & .094 & -.402 & -.213 & 1 \\
\hline
\end{tabular}

**The correlation is significant at the level 0.01 (two-tailed)

consequences, and risks were not correlated with business internationalization process among Paraguayan software firms. A summary of the results from phase 3 is presented in Table 3.

Phase 4 results indicated that criterion 17 , criterion 18, and criterion 19 were positively correlated with business internationalization processes. As a result, determining the factors and the most important criteria to make a decision, and then to use these factors by evaluating options, improved a firm's internationalization process. Similarly, being cautious in trusting opinions from employees and being careful when making decisions on foreign markets positively affected the success of a software firm in the international market. A summary of the findings from phase 4 is presented in Table 4.

Phase 5 findings revealed that criterion 20, criterion 21, and criterion 22 were correlated with the internationalization of software businesses. While criterion 22 was positively correlated with the internationalization process, criterion 20 and criterion 21 were negatively correlated with business internationalization. The results reveal that making personal decisions and strongly believing them without cross-verification negatively impacts the success of the internationalization process. Additionally, doubting decisions made during the internationalization deliberations can have negative impacts on the success of Paraguayan software firms in the international markets. In contrast,

Table 2 Correlation results for phase 1 analysis on decision-making

\begin{tabular}{lllllll}
\hline & Criterion & Criterion & Criterion & Criterion & Criterion & Criterion \\
& 5 & 6 & 7 & 8 & 9 & 10 \\
\hline $\begin{array}{l}\text { Criterion 5: I rely on my own home-market } \\
\text { experience to find solutions. }\end{array}$ & 1 & & & & \\
$\begin{array}{l}\text { Criterion 6: I try to learn from the successful } \\
\text { internationalization strategies of my }\end{array}$ & -.039 & 1 & & & \\
competitors. & & & & & \\
$\begin{array}{l}\text { Criterion 7: I consider a variety of potential } \\
\text { solutions like the comparison of different } \\
\text { market entry modes or the attractiveness of } \\
\text { different markets before I make my decision. }\end{array}$ & .082 & .260 & 1 & & \\
$\begin{array}{l}\text { Criterion 8: My solutions are mainly based on } \\
\text { market Opportunities like Personal contacts }\end{array}$ & .001 & .102 & .072 & 1 & \\
$\begin{array}{l}\text { to potential clients, existing clients, and } \\
\text { distributors in foreign markets }\end{array}$ & & & & & & \\
$\begin{array}{l}\text { Criterion 9: I always look for the solutions } \\
\text { with the lowest risk and cost (resource } \\
\text { requirements) }\end{array}$ & .018 & .181 & $.308^{*}$ & .128 & 1 \\
$\begin{array}{l}\text { Criterion 10: I use business intelligence } \\
\text { software to prepare solutions }\end{array}$ & -.131 & $.479^{* *}$ & $.305^{*}$ & .090 & -.062 & 1 \\
\hline
\end{tabular}

*The correlation is significant at the level 0.05 (two-tailed)

**The correlation is significant at the level 0.01 (two-tailed) 
Table 3 Correlation results for phase 3 analysis on decision-making

\begin{tabular}{lllll}
\hline & $\begin{array}{l}\text { Criterion } \\
11\end{array}$ & $\begin{array}{l}\text { Criterion } \\
12\end{array}$ & $\begin{array}{l}\text { Criterion } \\
13\end{array}$ & $\begin{array}{l}\text { Criterion } \\
14\end{array}$ \\
\hline $\begin{array}{l}\text { Criterion 11: Evaluate the risks and costs associated with each } \\
\text { alternative before making a decision. }\end{array}$ & 1 & & & \\
$\begin{array}{l}\text { Criterion 12: Sometimes I am surprised at the real consequences of } \\
\text { my decisions (more expensive, require more time). }\end{array}$ & -.108 & 1 & & \\
$\begin{array}{l}\text { Criterion 13: Some of the options I have chosen have been much } \\
\text { more difficult to implement than expected. }\end{array}$ & $-.318^{*}$ & .183 & 1 \\
$\begin{array}{l}\text { Criterion 14: I use business intelligence software to compare risks, } \\
\text { cost, consequences, and the feasibility of the different alternatives }\end{array}$ & -.187 & -.157 & 0.56 & 1 \\
\hline
\end{tabular}

*The correlation is significant at the level 0.05 (two-tailed)

when decision-makers evaluate their conclusions upon entering a new market once there is the availability of new information, the software firms are likely to succeed in this specific market. A summary of the results for phase 5 is presented in Table 5 .

Finally, results from phase 6 included criteria 24-27. All the decision processes in this phase were positively connected with business internationalization. Criterion 24 revealed that having a deployment plan before a decision-maker can communicate his or her choices about entry into new markets facilitates business success in a new foreign market. Criterion 25 also stressed that in communicating the decision-makers' resolution, it is important to include their basic reasoning and justification for a firm's entry into the international market. Criterion 26 also stressed the importance of confidence in communicating decisions so as to gain support for business internationalization plans. Lastly, criterion 27 indicated that using a step-by-step implementation reduces potential costs and risks (Table 6).

Pearson's correlation coefficient between key decision-maker characteristics (i.e., job experience and knowledge of business intelligence) and internationalization of software companies revealed a statistically significant relationship. The $p$ value is 0.05 , which is less than a 0.05 critical value or at a $95 \%$ confidence interval. However, the magnitude of the correlation is relatively small at 0.481 , which implies that key decision-maker characteristics are only about 50\% correlated with the success of Paraguayan software firms in the new foreign markets. Table 7 presents the results for the Pearson correlation coefficient.

Table 4 Correlation results for phase 4 analysis on decision-making

\begin{tabular}{|c|c|c|c|c|c|}
\hline & $\begin{array}{l}\text { Criterion } \\
15\end{array}$ & $\begin{array}{l}\text { Criterion } \\
16\end{array}$ & $\begin{array}{l}\text { Criterion } \\
17\end{array}$ & $\begin{array}{l}\text { Criterion } \\
18\end{array}$ & $\begin{array}{l}\text { Criterion } \\
19\end{array}$ \\
\hline $\begin{array}{l}\text { Criterion 15: I tend to have a strong "gut instinct" about } \\
\text { problems, and I rely on it in decision-making. }\end{array}$ & 1 & & & & \\
\hline $\begin{array}{l}\text { Criterion } 16: \text { I take the time to choose the best tools to } \\
\text { support decision making. }\end{array}$ & .070 & 1 & & & \\
\hline $\begin{array}{l}\text { Criterion 17: Determine the factors and the most } \\
\text { important criteria to make a decision, and then use } \\
\text { these factors to evaluate my options (for example, using } \\
\text { a BI software) }\end{array}$ & -0.05 & $.592^{* *}$ & 1 & & \\
\hline $\begin{array}{l}\text { Criterion 18: I tend to trust the opinions of my } \\
\text { employees or other experts in decision-making. }\end{array}$ & $.414^{* *}$ & .102 & .049 & 1 & \\
\hline $\begin{array}{l}\text { Criterion 19: I'm very careful to make decisions on } \\
\text { foreign markets without having enough information }\end{array}$ & .034 & .211 & $.430^{* *}$ & .282 & 1 \\
\hline
\end{tabular}

*The correlation is significant at the level 0.05 (two-tailed)

**The correlation is significant at the level 0.01 (two-tailed) 
Table 5 Correlation results for phase 5 analysis on decision-making

\begin{tabular}{lllll}
\hline & $\begin{array}{l}\text { Criterion } \\
20\end{array}$ & $\begin{array}{l}\text { Criterion } \\
21\end{array}$ & $\begin{array}{l}\text { Criterion } \\
22\end{array}$ & $\begin{array}{l}\text { Criterion } \\
23\end{array}$ \\
\hline $\begin{array}{l}\text { Criterion 20: After I make a decision, it's final-because I know my } \\
\text { process is strong. }\end{array}$ & 1 & & & \\
$\begin{array}{l}\text { Criterion 21: If I have doubts about my decision, I go back and } \\
\text { recheck my assumptions and my process }\end{array}$ & $-.361^{*}$ & 1 & \\
$\begin{array}{l}\text { Criterion 22: I evaluate my decisions during the process of entering } \\
\text { a new market if new information becomes available. }\end{array}$ & -.003 & $.365^{*}$ & 1 \\
$\begin{array}{l}\text { Criterion 23: Once the project is completed to market entry, I } \\
\text { discuss my decision to learn for future projects }\end{array}$ & -.072 & .086 & .270 & 1 \\
\hline
\end{tabular}

*The correlation is significant at the level 0.05 (two-tailed)

ANOVA results showed that the coefficient of decision-makers' characteristics $\left(\chi^{2}\right)$ has an estimated standard error of 6.832, F-statistic of 21.829, and $p$ value of 0.082 . Therefore, the impact of decision-makers' characteristic on the software firm's internationalization is significant at $95 \% \mathrm{CI}$ or at a $p$ value of 0.05 since $p<0.05$. The $\mathrm{H}_{0}$ is therefore rejected while the $\mathrm{H}_{\mathrm{a}}$ is confirmed.

$H_{a}$ : There is a statistically significant relationship between decision-makers job experience and business intelligence knowledge on the internationalization of Paraguayan SMEs.

\section{Discussion}

Vahlne and Johanson (2017) and Coviello et al. (2017) underlined the importance of decision-makers' influence on business internationalization. Especially, Vahlne and Johanson (2017) used the UIPM as a theory to discuss how decisions-makers might gain knowledge for business internationalization. This study confirmed the assumptions of Vahlne and Johanson (2017) that showed a correlational relationship between the variables "business experience" and "business internationalization" and extended them showing an additional correlational relationship between the variables "business intelligence knowledge" and "business internationalization."

Based on our results, it can be argued that decision-makers in the Paraguayan software companies influence the internationalization of their SMEs. The findings from this study have established that decision-makers play an important role in the internationalization of SMEs. Business experience and business intelligence

Table 6 Correlation results for phase 6 analysis on decision-making

\begin{tabular}{|c|c|c|c|c|}
\hline & $\begin{array}{l}\text { Criterion } \\
24\end{array}$ & $\begin{array}{l}\text { Criterion } \\
25\end{array}$ & $\begin{array}{l}\text { Criterion } \\
26\end{array}$ & $\begin{array}{l}\text { Criterion } \\
27\end{array}$ \\
\hline $\begin{array}{l}\text { Criterion 24: Before communicating my decisions about entry into } \\
\text { new markets, I develop a market entry plan. }\end{array}$ & 1 & & & \\
\hline $\begin{array}{l}\text { Criterion 25: In communicating my decision, I include my basic } \\
\text { reasoning and justification. }\end{array}$ & $.474^{* *}$ & 1 & & \\
\hline $\begin{array}{l}\text { Criterion 26: I emphasize how confident I am in my decision as a } \\
\text { way to gain support for my plans. }\end{array}$ & $.305^{*}$ & $.504^{* *}$ & 1 & \\
\hline $\begin{array}{l}\text { Criterion 27: I use an implementation process step by step to } \\
\text { reduce the risk and cost. This gives me the opportunity to review } \\
\text { my decision if new information during the implementation phase. }\end{array}$ & $.496^{* *}$ & $.348^{*}$ & $.303^{*}$ & 1 \\
\hline
\end{tabular}

*The correlation is significant at the level 0.05 (two-tailed)

**The correlation is significant at the level 0.01 (two-tailed) 
Table 7 Pearson correlation coefficient

\begin{tabular}{lllll}
\hline & \multicolumn{2}{l}{ Business internationalization } & \multicolumn{2}{l}{ Decision-makers' characteristics } \\
\cline { 5 - 5 } Business internationalization & Pearson correlation & 1 & $.478^{*}$ & $.488^{*}$ \\
& Sig. (two-tailed) & & .014 & 45 \\
& $N$ & 45 & 45 & 1 \\
Decision-makers' characteristics & Pearson correlation & $.481^{*}$ & 1 & \\
& Sig. (two-tailed) & .014 & & 45 \\
\hline
\end{tabular}

*The correlation is significant at the level 0.05 (two-tailed)

influence the 27-criterion importance during the decision-making processes. In both cases, experience and business intelligence largely influence the software firms' internationalization process. These findings are in line with past literature studies by Vahlne and Johanson (2017) and Neubert and Van Der Krogt $(2017,2018)$, which cited the important role of the decision-making process in a company's internationalization process.

Finally, our results suggest that both gaining knowledge through experience and through business intelligence as characteristics of decision-makers' is correlated positively with successful business internationalization.

\section{Conclusions}

This study examines the influence of decision-makers from Paraguayan software firms on internationalization. It aims to get a better understanding about the (non-)rational decision logic of the CEOs and founders shaping the internationalization processes of Paraguayan software firms. The research is based on the data from a representative sample of knowledgeable SMEs with a confidence level of $95 \%$ and a margin of error of $5 \%$ on the full population of Paraguayan software companies active in software development and related advisory services and uses an observational, comparative descriptive, and a descriptive correlational research design.

The valid and reliable results suggest a significant correlational impact of decisionmakers' characteristics on the Paraguayan software firm's internationalization. The variables "job experience" and "business intelligence knowledge" influence the 27-criteria of the decision-making processes and the software firms' internationalization process. These quantitative results are in line with past literature studies by Vahlne and Johanson (2017) and Coviello et al. (2017) and confirm the qualitative results provided by Neubert and Van Der Krogt $(2017,2018)$ and Neubert (2018a, 2018b), which cited the important role of the decision-making influence in a company's internationalization process.

The researchers suggest that the results of this survey might be relevant for both educators and practitioners (entrepreneur/senior manager). Educators might redesign their curricula to facilitate knowledge creation from experience and how to integrate business intelligence systems in the international decision-making processes. Entrepreneurs might gain confidence, when relying on their experience and motivation, to use business intelligence systems, which will support their decision-making processes. The 
following traits are probably needed for successful business internationalization: the ability to learn from experience and business intelligence.

The results of this study contribute to the existing literature in international entrepreneurship following a call for research from Coviello et al. (2017) and a need to better understand the influence of decision-makers on internationalization of their firms. The results are relevant for academics and international decisionmakers, who support the development, training, and application of the decisionmaking processes, business intelligence systems, and their impact on the export performance and internationalization of Paraguayan software firms. Future scholarly work should include quantitative and qualitative assessments of the variables "decision-makers job experience" and "business intelligence knowledge." These concepts exist in different contexts in a variety of industries in emerging, as well as in developed markets. In essence, this happens to encourage a deeper understanding of the influence of decision-makers on internationalization.

Abbreviations

BGF: Born global firm; HSF: High-tech start-up firm; ICT: Information and communication technology; INV: International new venture; LGS: Lean global start-up; SME: Small- and medium-sized enterprise; SMOPEC: Small and open economy; TIC: Tecnologías de la Información y Comunicación; UIPM: Uppsala internationalization process model

\section{Acknowledgements}

None

\section{About the authors}

Michael Neubert is a Professor at the International School of Management in Paris, France, where he obtained his PhD and is now also Chair of the Strategic Management Committee. Michael is also a Visiting Professor at Universidad Paraguayo Alemana in San Lorenzo, Paraguay. He teaches international business, intercultural communication, doing business in foreign markets, and international finance. His research interests concern the internationalization of hightech startups. Michael is a member of the Academy of International Business, and he is a partner of a private equity firm that invests in high-tech startups and supports them in the development of new foreign markets. Michael is also the CEO of C2NM (www.c2nm.com), a Swiss consulting firm specializing in the field of international and intercultural management.

Augustinus (Stijn) Van Der Krogt is the Dean of the Faculty of Business Administration at the Universidad Paraguayo Alemana in San Lorenzo, Paraguay. He is also a Director of the consulting firm Changing Values International, which accompanies private and public organizations in their process of change by providing tailor-made strategic advice and executive training and coaching.

\section{Authors' contributions}

Each author made substantial contributions, approved the submitted version, and agreed both to be personally accountable for the author's own contributions and to ensure that questions related to the accuracy or integrity of any part of the work, even ones in which the author was not personally involved, are appropriately investigated, resolved, and the resolution documented in the literature.

Funding

There is no funding.

\section{Availability of data and materials}

The datasets used and/or analyzed during the current study are available from the corresponding author on reasonable request.

\section{Competing interests}

The authors declare that they have no competing interests.

\section{Author details}

${ }^{1}$ ISM International School of Management, 17, Boulevard Raspail, 75007 Paris, France. ${ }^{2}$ UPA Universidad Paraguaya Alemana, Lope de Vega, 1279 Asuncion, Paraguay.

Received: 8 August 2019 Accepted: 8 November 2019

Published online: 31 December 2019

References

Bryman, A. (2012). Social research methods (5th ed.). Oxford: Oxford University Press. 
Cerrato, D., \& Piva, M. (2015). The internationalization of small and medium-sized enterprises: the effect of family management, human capital and foreign ownership. Journal of Management \& Governance, 16(4), 617-644. https://doi. org/10.1007/s10997-010-9166-X.

Clarke, J. E., \& Liesch, P. W. (2017). Wait-and-see strategy: Risk management in the internationalization process model. Journal of International Business Studies, 48(8), 923-940. https://doi.org/10.1057/s41267-017-0110-z.

Coudounaris, D. N. (2018). Typologies of internationalisation pathways of SMEs: what is new? Review of International Business and Strategy, 28(3/4), 286-316 https://doi.org/10.1108/RIBS-12-2017-0119.

Coviello, N., Kano, L., \& Liesch, P. W. (2017). Adapting the Uppsala model to a modern world: Macro-context and microfoundations. Journal of International Business Studies, 48(9), 1151-1164 https://doi.org/10.1057/s41267-017-0120-x.

Creswell, J. W., \& Creswell, J. D. (2017). Research design: Qualitative, quantitative, and mixed methods approaches. Sage publications.

Easterby-Smith, M., Thorpe, R., \& Jackson, P. (2014). Management Research (4th ed.). London: Sage publications.

Falahat, M., Knight, G., \& Alon, I. (2018). Orientations and capabilities of born global firms from emerging markets. International Marketing Review, 35(6), 936-957 https://doi.org/10.1108/IMR-01-2017-0021.

Goddard, W., \& Melville, S. (2004). Research methodology: An introduction. Juta and Company Ltd.

Gulanowski, D., Papadopoulos, N., \& Plante, L. (2018). The role of knowledge in international expansion: Toward an integration of competing models of internationalization. Review of International Business and Strategy, 28(1), 35-60 https://doi.org/10.1108/RIBS-09-2017-0077.

Gulati, P. M. (2009). Research management: Fundamental and applied research. New Delhi: Global India Productions.

Håkanson, L., \& Kappen, P. (2017). The 'casino model'of internationalization: An alternative Uppsala paradigm. Journal of International Business Studies, 48(9), 1103-1113 https://doi.org/10.1057/s41267-017-0113-9.

Johanson, J., \& Vahlne, J. E. (2009). The Uppsala internationalization process model revisited: From liability of foreignness to liability of outsidership. Journal of international business studies, 40(9), 1411-1431 https://doi.org/10.1057/jibs.2009.24.

Knight, G. A., \& Liesch, P. W. (2016). Internationalization: From incremental to born global. Journal of World Business, 51(1), $93-$ 102 https://doi.org/10.1016/j.jwb.2015.08.011.

Kriz, A., \& Welch, C. (2018). Innovation and internationalisation processes of firms with new-to-the-world technologies. Journal of International Business Studies, 49(4), 496-522 https://doi.org/10.1057/s41267-018-0147-7.

Magnani, G., Zucchella, A., \& Floriani, D. E. (2018). The logic behind foreign market selection: Objective distance dimensions vs. strategic objectives and psychic distance. International Business Review, 27(1), 1-20 https://doi.org/10.1016/j.ibusrev.2017.10.009.

Musso, F., \& Francioni, B. (2012). The influence of decision-maker characteristics on the international strategic decision-making process: An SME perspective. Procedia - Social and Behavioral Sciences, 58, 279-288. https://doi.org/10.1016/j.sbspro.2012.09.1002.

Neubert, M. (2015). Early internationalisation of high-tech firms: Past accomplishments and future directions. International Journal of Teaching and Case. Studies, 6(4), 353-369. https://doi.org/10.1504/IJTCS.2015.074603.

Neubert, M. (2017). Lean Internationalization: How to globalize early and fast in a small economy. Technology Innovation Management Review, 7(5), 16-22 https://doi.org/10.22215/timreview/1073

Neubert, M. (2018a). The impact of digitalization on the speed of internationalization of lean global startups. Technology Innovation Management Review, 8(5), 44-54 https://doi.org/10.22215/timreview/1158.

Neubert, M. (2018b). Internationalisation behaviour of small and medium-sized enterprises from emerging markets: implications for sustainability. Latin American Journal of Management for Sustainable Development, 4(3), 226-238 https:// doi.org/10.1504/LAJMSD.2018.096072.

Neubert, M., \& Van Der Krogt, A. (2017). Lean internationalisation of high-tech firms. International Journal Teaching and Case Studies, 8(2/3), 133-150 https://doi.org/10.1504/IJTCS.2017.086679.

Neubert, M., \& Van der Krogt, A. (2018). Impact of business intelligence solutions on export performance of software firms in emerging economies. Technology Innovation Management Review, 8(9), 39-49 https://doi.org/10.22215/timreview/1185.

Ooi, S. M., \& Richardson, C. (2019). The internationalisation of service-sector SMEs in an emerging market: Insights from business training and consultancy firms in Malaysia. Review of International Business and Strategy, 29(1), 44-60 https://doi. org/10.1108/RIBS-02-2018-0023.

Senatics (2014). Encuesta de empresas del sector de TICs. Asuncion, Paraguay. Secretaria Nacional de Tecnologías de la Información y Comunicación.

Santangelo, G. D., \& Meyer, K. E. (2017). Internationalization as an evolutionary process. Journal of International Business Studies, 48(9), 1114-1130 https://doi.org/10.1057/s41267-017-0119-3.

Sapouna, P., Dimitratos, P., Larimo, J., \& Zucchella, A. (2018). Market withdrawal, international orientation and internationa marketing: Effects on SME performance in foreign markets. In Advances in Global Marketing (pp. 281-303). Cham: Springer https://doi.org/10.1007/978-3-319-61385-7_12.

Vahlne, J., \& Johanson, J. (2013). The Uppsala model on evolution of the multinational business enterprise - from internalization to coordination of networks. International Marketing Review, 30(3), 189-210 https://doi.org/10.1108/ 02651331311321963.

Vahlne, J. E., \& Johanson, J. (2017). From internationalization to evolution: The Uppsala model at 40 years. Journal of International Business Studies, 48(9), 1087-1102 https://doi.org/10.1057/s41267-017-0107-7.

World Bank (2016). Paraguay - country profile. retrieved from: https://data.worldbank.org/country/paraguay. Accessed December 2, 2019

Yamin, M., \& Kurt, Y. (2018). Revisiting the Uppsala internationalization model: Social network theory and overcoming the liability of outsidership. International Marketing Review, 35(1), 2-17 https://doi.org/10.1108/IMR-11-2014-0345.

Yin, R. K. (2017). Case study research and applications: Design and methods. Sage publications.

\section{Publisher's Note}

Springer Nature remains neutral with regard to jurisdictional claims in published maps and institutional affiliations. 